\title{
Comparative evaluation of different organic fertilizer on the soil fertility, leaf mineral composition, and growth performance of mango seedlings (Magnifera indica L.)
}

\author{
Moyin-Jesu, E. I. ${ }^{1}$ and C. O. Adeofun ${ }^{2}$ \\ ${ }^{1}$ Agronomy Department, Federal College of Agriculture, Akure, Ondo-State, Nigeria. \\ ${ }^{2}$ College of Environmental Studies, University of Agriculture, Abeokuta, Ogun State, \\ Nigeria
}

\begin{abstract}
An investigation was carried out at Akure in the rainforest of Nigeria to determine the effectiveness of sole and amended oil palm bunch ash and spent grain with poultry and turkey manures as sources of fertilizers on the growth of mango seedlings (Magnifera indica L) in the nursery. Eight organic fertilizer treatments, spent grain, oil palm bunch ash, poultry manure, turkey manures (sole forms), oil palm bunch ash + poultry manure, oil palm bunch ash + turkey manure, spent grain + poultry manure, spent grain + turkey manure, were applied at $8 \mathrm{t} / \mathrm{ha}$ (40g per $10 \mathrm{~kg}$ soil filled poly bag) with an NPK fertilizer $400 \mathrm{~kg} / \mathrm{ha}(2 \mathrm{~g}$ per bag) treatment as a reference and a control (no fertilizer; no manure), replicated three times and arranged in a completely randomized design. The results showed that the organic fertilizers increased significantly $(\mathrm{P}<0.05)$ plant height, leaf area, stem girth, number of leaves of mango seedlings and root length, soil and leaf $\mathrm{N}, \mathrm{P}, \mathrm{K}, \mathrm{Ca}$ and $\mathrm{Mg}$, soil $\mathrm{pH}$ and organic matter contents relative to the control treatment. Oil palm bunch ash + poultry manure treatment increased the plant height, stem girth, leaf area, leaf number and root length of mango seedlings by $22 \%, 24 \%$, $1 \%, 27 \%$ and $10 \%$ respectively, compared to NPK $15-15-15$ fertilizer treatment. Amended oil palm bunch ash + poultry manure treatment also increased the soil $\mathrm{pH}\left(\mathrm{H}_{2} \mathrm{O}\right)$, O.M., N, P, Ca and $\mathrm{Mg}$ by $27 \%, 79 \%, 30 \%, 26 \%, 99 \%$ and $99.2 \%$ respectively compared to NPK fertilizer treatment. In addition, it also increased the leaf $\mathrm{N}, \mathrm{P}, \mathrm{K}, \mathrm{Ca}$ and $\mathrm{Mg}$ by $37 \%, 45 \%, 18 \%, 35 \%$, and $15 \%$ respectively compared to the oil palm bunch ash (sole) treatment. However, NPK 1515-15 fertilizers increased only soil $\mathrm{K}$ by $10 \%$ compared to the oil palm bunch ash (sole) treatment. The highest soil $\mathrm{K} / \mathrm{Ca}, \mathrm{K} / \mathrm{Mg}$ and $\mathrm{P} / \mathrm{Mg}$ ratios in NPK fertilizer treatment led to imbalance in the supply of $\mathrm{P}, \mathrm{K}, \mathrm{Ca}$ and $\mathrm{Mg}$ nutrients to mango. Oil palm bunch ash + poultry manure treatment applied at $8 \mathrm{t} / \mathrm{ha}$ was the most effective treatment in improving mango growth parameters, leaf mineral composition, and soil fertility.
\end{abstract}

Key words: Organic fertilizers, soil fertility, leaf mineral composition, growth performance and mango seedlings.

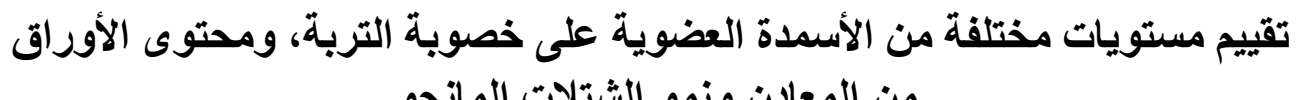

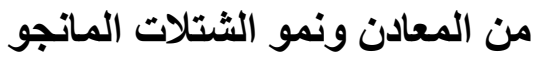

$$
\begin{aligned}
& \text { ا. أي. معين-جيسو } 1 \text { ؛ سي. أو. اديوفن2 } \\
& \text { 1ققسم المحاصيل، كلية الزراعة الاتحادية، أكور، ولاية أوندو، نيجيريا2 كلية الدراسات البيئية، الجامعة الزراعية، أبوكوتا، } \\
& \text { ولاية أوجن، نيجيريا } \\
& \text { الملضص: أجريت التجربة في في الغابات المطيرة في اكيور في نيجيريا بهدف دراسة تأثير إضافة زيت رماد عذوق النخيل }
\end{aligned}
$$

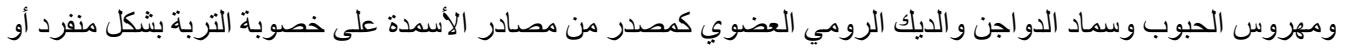

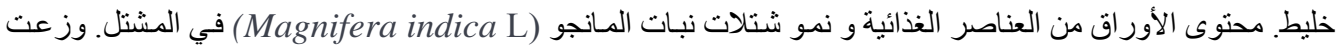

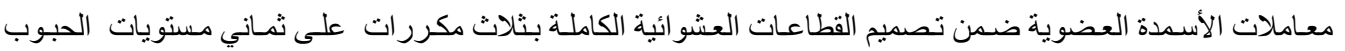

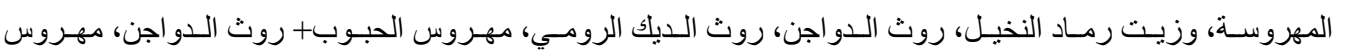

$$
\begin{aligned}
& \text { الحبوب+روث الديك الرومي، زيت رماد عذوق النخيل+ روث الدواجن و زيت رمـاد عذوق النخيل+ روث الديك الرومي }
\end{aligned}
$$




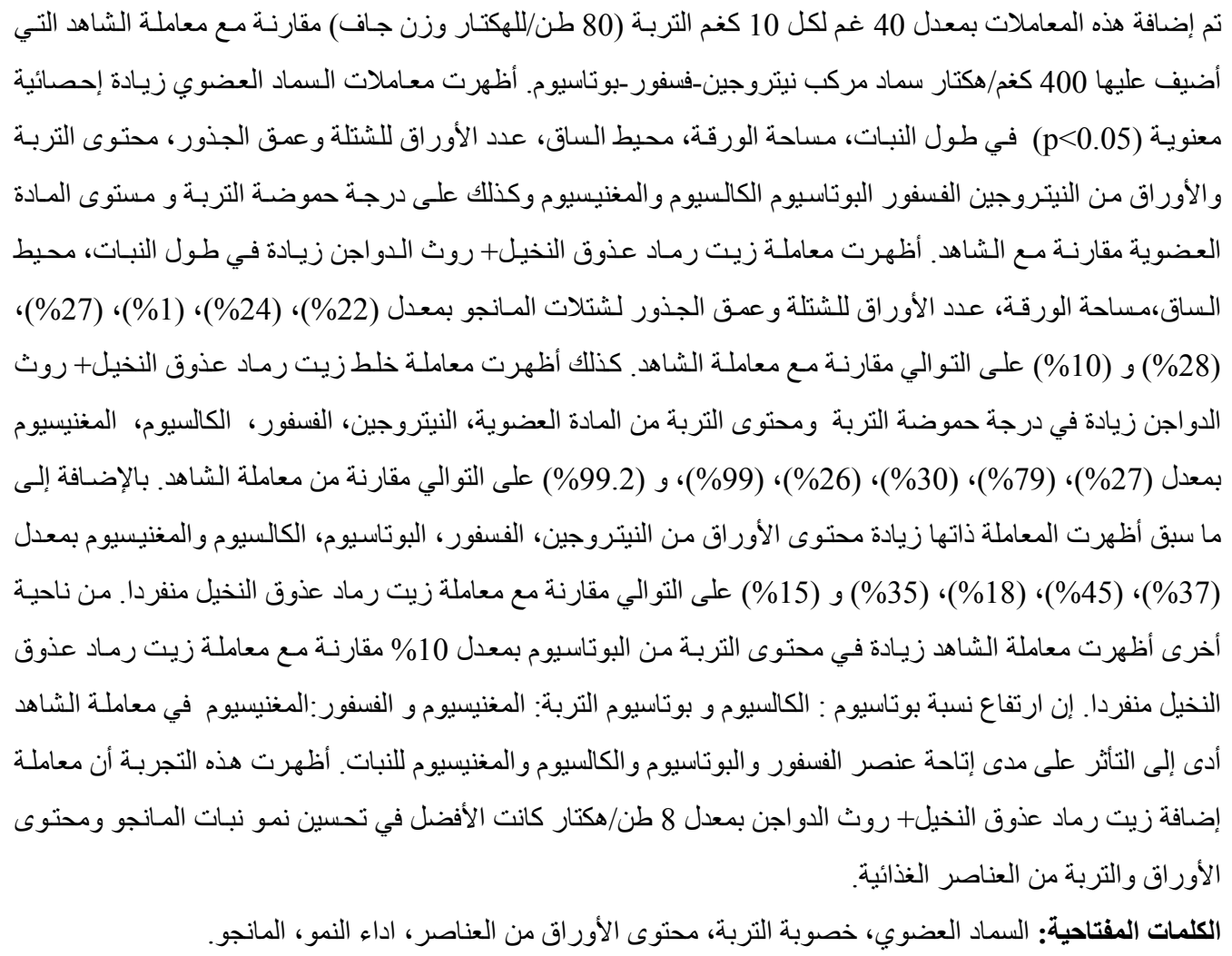

\section{Introduction}

Mango (Magnifera indica) belongs to the family Anacardiaceae and produce fleshy drupe fruits which are eaten raw, canned, or used for making juices, jams, and other preservations. In spite of the great economic importance of the crop in Nigeria, large-scale cultivation of mango has not been attained, partly because of shortage of mango seedlings and the practice of planting mango seeds directly to the field by farmers without nursery practice. Most of these seeds sown did not germinate on time or the seedlings did not grow very well as a result of shock from weather variations or water stress. This situation is worsened by continued decline in soil fertility and efforts to supplement the soil nutrients with inorganic fertilizers to support the germination and growth of mango crop are hampered by the high cost of purchase, acute scarcity, and destruction of the soil properties on continuous use Aduayi (1980); Agbede and Kalu (1990)
Obi and Ofoduru (1997). The tendency to supply all plant nutrients through chemical fertilizers should be reconsidered now or in the future because this has a deleterious effect on soil productivity on a long term basis Yadav and Prassad (1992). Therefore, there is a strong justification to look for alternative locally sourced organic fertilizers materials which are cheap, sustainable and environmentally compatible to raise mango seedlings in large quantities for the establishment of commercial plantations and as well as providing foreign exchange earnings for tropical countries. Except, Obatolu (1995), Moyin-Jesu and Atoyosoye (2002), Moyin-Jesu (2003a), Moyin-Jesu and Ojeniyi (2006) and Moyin-Jesu (2007) who reported the use of cocoa pod, spent grain, poultry manure and rice bran to grow coffee, cocoa, okra and Amaranthus respectively, there is scarcity of research information on the use of poultry manure, 
turkey manure, cocoa husk, spent grain and oil palm bunch ash to raise mango seedlings in the nursery and field establishment.

The objectives of this study were (i) to determine the growth performance of mango seedlings as influenced by the application of different organic fertilizers in the nursery. (ii) to determine the effect of these organic fertilizers on the leaf composition of mango seedlings and soil chemical composition after the experiment.

\section{Materials and Methods}

The experiment was carried out at Akure in the rainforest zone of Nigeria in 2001 and was repeated in 2002 to validate the results. The soil is sandy clay loam, skeletal, kaolinitic, isohyperthermic oxic paleustalf (Alfisol). Soil Survey Staff (1999). The annual rainfall is between 1100 and $1500 \mathrm{~mm}$ while the average temperature is $24{ }^{\circ} \mathrm{C}$.

\section{Soil Sampling and Analysis before Planting}

Thirty core samples were collected randomly from $0-15 \mathrm{~cm}$ depth on the site using soil auger, mixed thoroughly and the bulk sample was taken to the laboratory, air-dried, and sieved to pass through a $2 \mathrm{~mm}$ screen for chemical analysis. The soil $\mathrm{pH}(1: 1 \mathrm{soil} /$ water $)$ and $\left(1: 2\right.$ soil/ $\left.0.01 \mathrm{M} \mathrm{CaCl}_{2}\right)$ solution was determined using a glass calomel electrode system Crockford and Nowell (1956) while organic matter was determined by the wet oxidation chromic acid digestion method Walkey and Black (1934). The total nitrogen was determined by the micro kjedahl method (AOAC, 1970) while available soil phosphorus was extracted by the Bray $\mathrm{P}_{1}$ extractant and measured by the Murphy blue coloration and determined on a spectronic 20 at 882um (Murphy and Riley, 1962). Soil K, $\mathrm{Ca}, \mathrm{Mg}$ and $\mathrm{Na}$ were extracted with $1 \mathrm{M} \mathrm{NH} \mathrm{N}_{4} \mathrm{OAC} \mathrm{pH} 7$ solutions. The $\mathrm{K}, \mathrm{Ca}$ and $\mathrm{Na}$ contents were determined with flame photometer while $\mathrm{Mg}$ was determined with an atomic absorption spectrophotometers (Jackson, 1958). The exchangeable acidity $\left(\mathrm{H}^{+}\right.$and $\mathrm{Al}^{+3}$ ) were determined using $0.01 \mathrm{M} \mathrm{HCl}$ extracts and titrated with $0.1 \mathrm{M} \mathrm{Na} \mathrm{OH}$ (Mc Lean, 1965) while the micronutrients $(\mathrm{Mn}, \mathrm{Cu}, \mathrm{Fe}$ and $\mathrm{Zn}$ ) were extracted with $0.1 \mathrm{M} \mathrm{HCl}$ (Ogunwale and Udo, 1998) and read on Perkin Elmer atomic absorption spectrophotometer. The mechanical analysis of the soil was done by the hydrometer method (Bouycous, 1951).

\section{Source and Preparation of Organic Fertilizers}

Spent grain and oil palm bunch ash were obtained from the International Breweries Limited and oil palm processing unit of Federal College of Agriculture, Akure respectively. The poultry and turkey manure were obtained from their pens in the livestock unit of Federal College of Agriculture, Akure. The organic materials were processed to allow decomposition. The oil palm bunch ash was sieved to remove the pebbles, stones and unburnt shafts while the spent grain was partially composed for 6 weeks to reduce the $\mathrm{C} / \mathrm{N}$ ratio. The turkey and poultry manures were air-dried to allow quick mineralization process.

\section{Chemical Analysis of the Organic Materials}

Two grams each of the processed forms of the organic materials used were analyzed. The nitrogen content was determined by Kjedahl method Jackson (1964) while the determination of other nutrients such as $\mathrm{P}, \mathrm{K}, \mathrm{Ca}, \mathrm{Mg}, \mathrm{Fe} \mathrm{Zn}, \mathrm{Cu}$ and $\mathrm{Mn}$ was done using the wet digestion method based on 25-5-5ml of $\mathrm{HNO}_{3}-\mathrm{H}_{2}$ $\mathrm{SO}_{4}-\mathrm{HClO}_{4}$ acids (AOAC, 1970). The organic carbon was determined by wet oxidation method through chronic acid digestion Walkley and Black (1934). 
Collection of Mango Seeds for Planting

Ripe fruits of mango were collected from the mango tree plantation in Federal College of Agriculture, Akure. The seeds were obtained after extraction of the juice from the fruits at the micro-processing unit of the college, washed and air-dried for 72 hours at room temperature to remove the moisture. The seed coats were scarified to hasten germination.

\section{Nursery Establishment of Mango Seedlings}

The site was cleared to remove weeds and other debris and a shed was erected for the nursery. The bulk soil taken from the site $(0-15 \mathrm{~cm}$ depth) was sieved to remove stones and plant debris, $10 \mathrm{~kg}$ of the sieved soil was placed into a poly bag $(30 \times 17 \mathrm{~cm})$.

There were eight treatments namely: poultry manure, turkey manure, spent grain, oil palm bunch ash, spent grain + poultry manure, spent grain + turkey manure, oil palm bunch ash + turkey manure, oil palm bunch ash + poultry manure. $40 \mathrm{~g}$ of each organic treatment was applied to $10 \mathrm{~kg}$ soil (8t/ha) with three replications and arranged in a completely randomized block design (CRD). A treatment with $400 \mathrm{~kg} / \mathrm{ha}$ NPK $15-15-15$ (2g per $10 \mathrm{~kg}$ soil) served as a reference along with a control (no fertilizer, no manure). The amended treatments were applied at a ratio 50: $50 \%$ by weight ( $20 \mathrm{~g}$ each).

The treatments were incorporated into the soil using hand trowel and allowed to decompose for one week before planting mango seeds to the poly bags. Watering was done immediately and continued every morning and evening between April and May, later it was reduced to once in a day when the rains were steady. The seeds germinated after 21 days of planting. Weeding started one week after germination and continued at two weeks interval until 20 weeks after planting. Spraying of karate (Lamba cyhalotrin) at $2 \mathrm{ml}$ a.i /6 liters of water against capsids and army worms was done at 3 weeks interval.

The measurement of growth parameters such as plant height, leaf area, leaf population and, stem girth started at the fifth week after planting and continued weekly until 20 weeks after planting (WAP).

Representative leaf samples from top, middle, and lower parts of the seedlings were randomly taken at 21 weeks after transplanting per each treatment using a knife, packed into labeled envelopes and oven dried for 24 hours at $70{ }^{\circ} \mathrm{C}$. The dried leaf samples were dry ashed using muffle furnace at $450{ }^{\circ} \mathrm{C}$ for 6 hours and the ash was made into solution, filtered and analyzed for $\mathrm{N}, \mathrm{P}, \mathrm{K}, \mathrm{Ca}$ and $\mathrm{Mg}$ as described earlier. At 24 weeks after planting in the nursery, the seedlings were ready for final transplanting in the field and the shoots were carefully uprooted and the root length measurement was taken for each treatment. At the end of the experiment, soil samples were also taken from each treatment, air-dried, sieved using $2 \mathrm{~mm}$ sieve and analyzed for $\mathrm{N}, \mathrm{P}, \mathrm{K}, \mathrm{Ca}, \mathrm{Mg}$, Soil $\mathrm{pH}$ and O.M. as described earlier.

\section{Statistical Analysis}

The average data obtained for the growth parameters, leaf and soil chemical composition of mango seedlings in 2001 and 2002 were analyzed using ANOVA F-test. The experimental design of the experiment was completely randomized design (CRD) with three replicates while the treatment means were compared using Duncan Multiple Range Test at 5\% level Gomez and Gomez (1984).

\section{Results}

\section{Soil Chemical Composition before Planting}

The chemical properties of the soil before planting are presented in (Figure 1). Based on the established critical levels for soils in South west Nigeria, the soil 
was slightly acidic with $\mathrm{pH} 5.6$ and low in organic matter compared to the critical level of 3\% O. M. Agboola and Corey (1973). The total nitrogen $(0.1 \%)$ is less than $0.15 \%$ which is considered optimal for most crops (Sobulo and Osiname 1981) while the available $P$ is less than 10 $\mathrm{mg} / \mathrm{kg} \mathrm{P}$ considered as optimum for crop production (Agboola and Corey, 1973).
The exchangeable $\mathrm{K}, \mathrm{Ca}, \mathrm{Mg}$ and $\mathrm{Na}$ contents were lower than $0.2 \mathrm{mmol} / \mathrm{kg}$ critical levels considered as adequate for crops (Folorunso et al., 2000), thus, indicating poor soil fertility status. The soil texture is sandy loam belonging to Akure series which is equivalent to Alfisol (Isohyperthermic oxic paleustalf). Soil Survey Staff (1999).

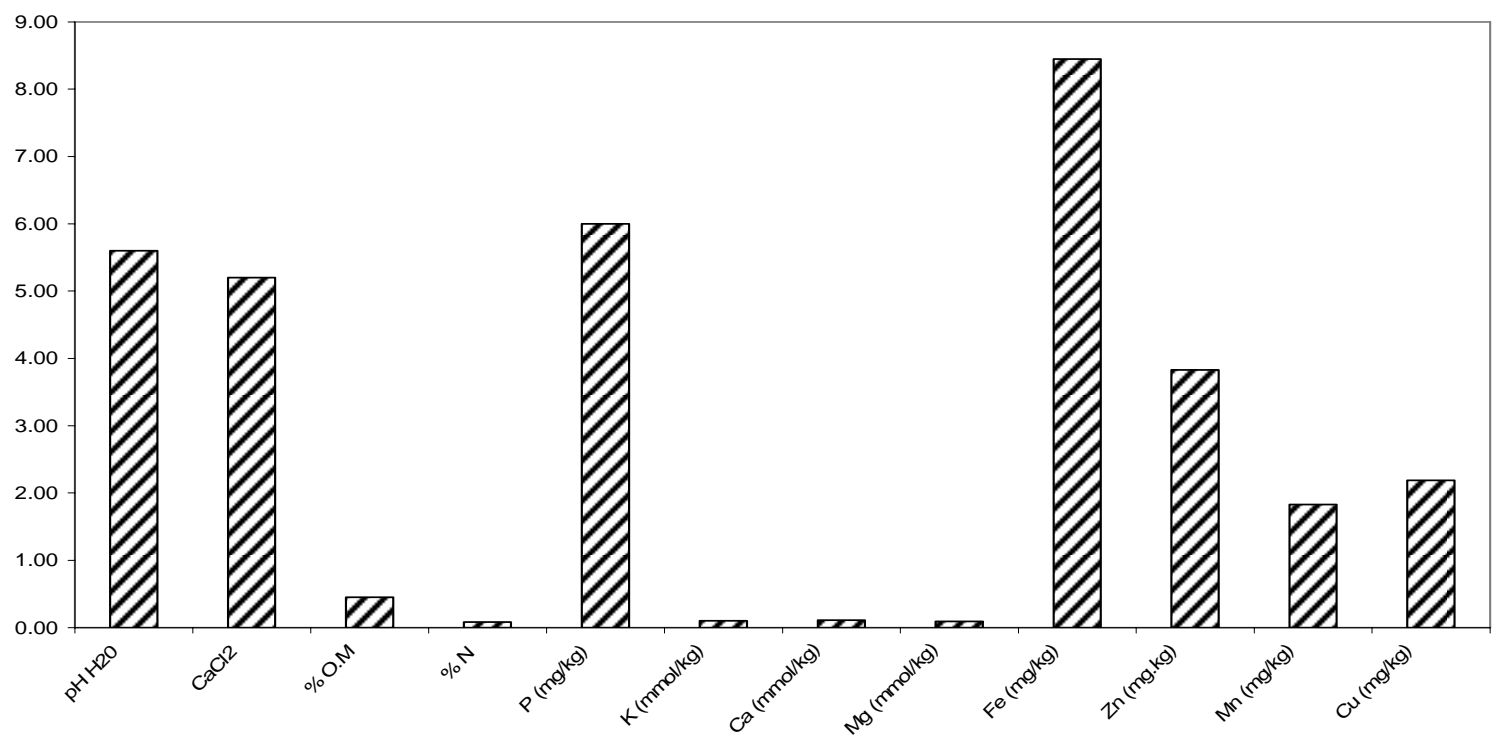

Fig 1: Chemical analysis of the soil before planting mango seedlings

Chemical Composition of the Organic Fertilizers Used In the Experiment

The composition of the organic fertilizer material used for raising mango seedlings is presented in (Figure 2). Poultry manure had the highest values of $\mathrm{N}$ and $\mathrm{P}$ nutrients and the least $\mathrm{C} / \mathrm{N}$ ratio of 6.93 compared to others. The oil palm bunch ash had the highest $\mathrm{K}(2.1 \%), \mathrm{Ca}$ $(0.93 \%)$ and $\mathrm{Mg}(0.70 \%)$ values respectively compared to poultry manure, turkey manures and spent grain respectively.

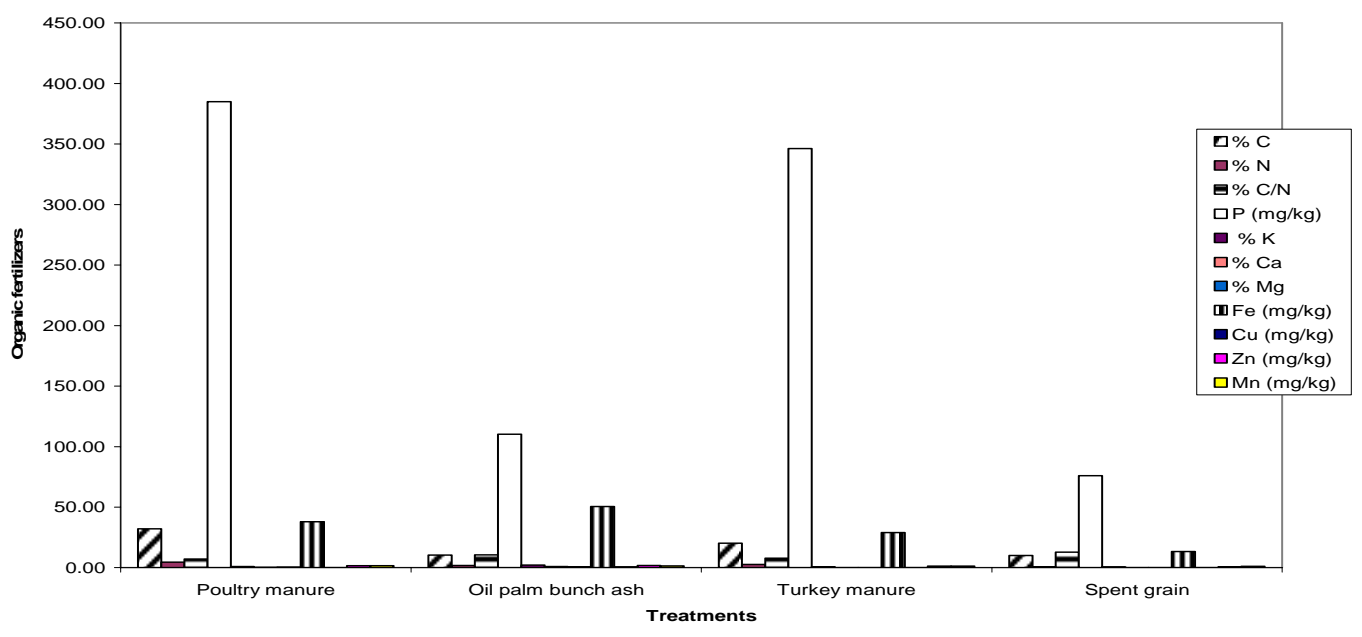

Fig 2: Chemical characteristics of organic fertilizers used for the field experiments 


\section{Effect of Organic Fertilizers on the Growth Performances of Mango Seedlings}

There were significant increases $(\mathrm{P}<0.05)$ in the plant height, stem girth, leaf area, leaf number and root length of mango seedlings under different organic fertilizers compared to the control treatment (Figure 3).

Oil palm bunch ash + poultry manure increased the plant height, stem girth, leaf area, leaf number and root length of mango seedling by $22 \%, 24 \%, 1 \%, 27 \%$ and $10 \%$ respectively, compared to NPK 15-15-15 fertilizer treatment.

When compared to sole application of oil palm bunch ash, oil palm bunch ash; oil palm bunch ash + poultry manure increased significantly $(\mathrm{P}<0.05)$ the plant height, stem girth, leaf area, leaf number and root length by $16 \%, 52.4 \%, 47 \%$, $33 \%$ and $52 \%$ respectively compared to the sole form of oil palm bunch ash.

Among the amended forms of oil palm bunch ash and spent grain with poultry and turkey manures. Oil palm bunch ash + poultry manure increased significantly $(\mathrm{P}<0.05)$ the stem girth, leaf area, leaf population and root length of mango seedlings except in the plant height where spent grain + poultry manure treatment had the highest value.

In addition, among the sole treatments, poultry manure treatment had the highest values of mango seedlings stem girth, leaf number, and root length compared to others while turkey manure treatment has the highest value of plant height.

The correlation(r) values among the dependent variables (plant height, stem girth, leaf area and root length were positive and significant at $1 \%$ and $5 \%$ level (Table 1). For instance, the ' $r$ ' values between plant height and stem girth, plant and root length, stem girth and leaf population, root length and leaf population were $0.757,0.816,0.790$ and 0.877 respectively at $1 \%$ level of significance.

\section{Effect of Organic Fertilizers on Leaf Chemical Composition of Mango Seedlings}

There were significant increases $(\mathrm{P}<0.05)$ in leaf $\mathrm{N}, \mathrm{P}, \mathrm{K}, \mathrm{Ca}$ and $\mathrm{Mg}$ compared to the control treatment (Figure 4). Oil palm bunch ash + poultry manure increased leaf $\mathrm{P}, \mathrm{K}, \mathrm{Ca}$ and $\mathrm{Mg}$ by $3 \%$, $11 \%, \quad 95 \%$ and $91 \%$ respectively compared to NPK fertilizer treatment. It also increased the leaf $\mathrm{N}, \mathrm{P}, \mathrm{K}, \mathrm{Ca}$ and $\mathrm{Mg}$ by $37 \%, 45 \%, 18 \%, 35 \%$, and $15 \%$ compared to the sole form of oil palm bunch ash. Among the amended organic fertilizers with poultry and turkey manures, oil palm bunch ash + poultry manure had the highest values of mango leaf $\mathrm{N}, \mathrm{P}, \mathrm{K}, \mathrm{Ca}$ and $\mathrm{Mg}$ followed by oil palm bunch ash + turkey manure, spent grain + poultry manure and spent grain + turkey manure respectively. For instance, the oil palm bunch ash + poultry manure increased the leaf $\mathrm{N}, \mathrm{P}, \mathrm{K}, \mathrm{Ca}$ and $\mathrm{Mg}$ of mango seedlings by $12 \%, 24 \%, 14 \%$, $10 \%$ and $13 \%$ compared to that of spent grain + turkey manure treatment respectively. For the sole application of the treatments, oil palm bunch ash had the highest values of mango leaf $\mathrm{K}, \mathrm{Ca}$ and $\mathrm{Mg}$ while the poultry manure had the highest values of $\mathrm{N}$ and $\mathrm{P}$.

The mango leaf $\mathrm{K} / \mathrm{Ca}$, and $\mathrm{K} / \mathrm{Mg}$ ratios were 1: 49 and 1: 54 under NPK 15-15-15 fertilizer treatment compared to $\mathrm{K} / \mathrm{Ca}(1: 3)$ and $\mathrm{K} / \mathrm{Mg}(1: 6)$ under oil palm bunch ash + poultry bunch ash + poultry manure treatment.

The correlation(r) values between leaf $\mathrm{N}, \mathrm{P}, \mathrm{K}, \mathrm{Ca}$ and $\mathrm{Mg}$ and growth parameters of mango seedlings were positive and significant at $(\mathrm{P}<0.01$ and $0.05)$ Table 2 signifying the importance of the positive relationship between nutrient uptake in the leaves and growth parameters of mango seedlings. For instance, the " $r$ " values between plant height and leaf $\mathrm{K}$ stem girth and leaf $\mathrm{N}$, leaf area and leaf $\mathrm{P}$, root length and leaf $\mathrm{Ca}$, leaf population and leaf $\mathrm{N}$ were $0.768,0.892,0.873,0.656$ and 0.663 
Emir. J. Food Agric. 2008. 20 (1): 18-30

http://www.cfa.uaeu.ac.ae/research/ejfa.htm

respectively at $1 \%$ and $5 \%$ level of significance.

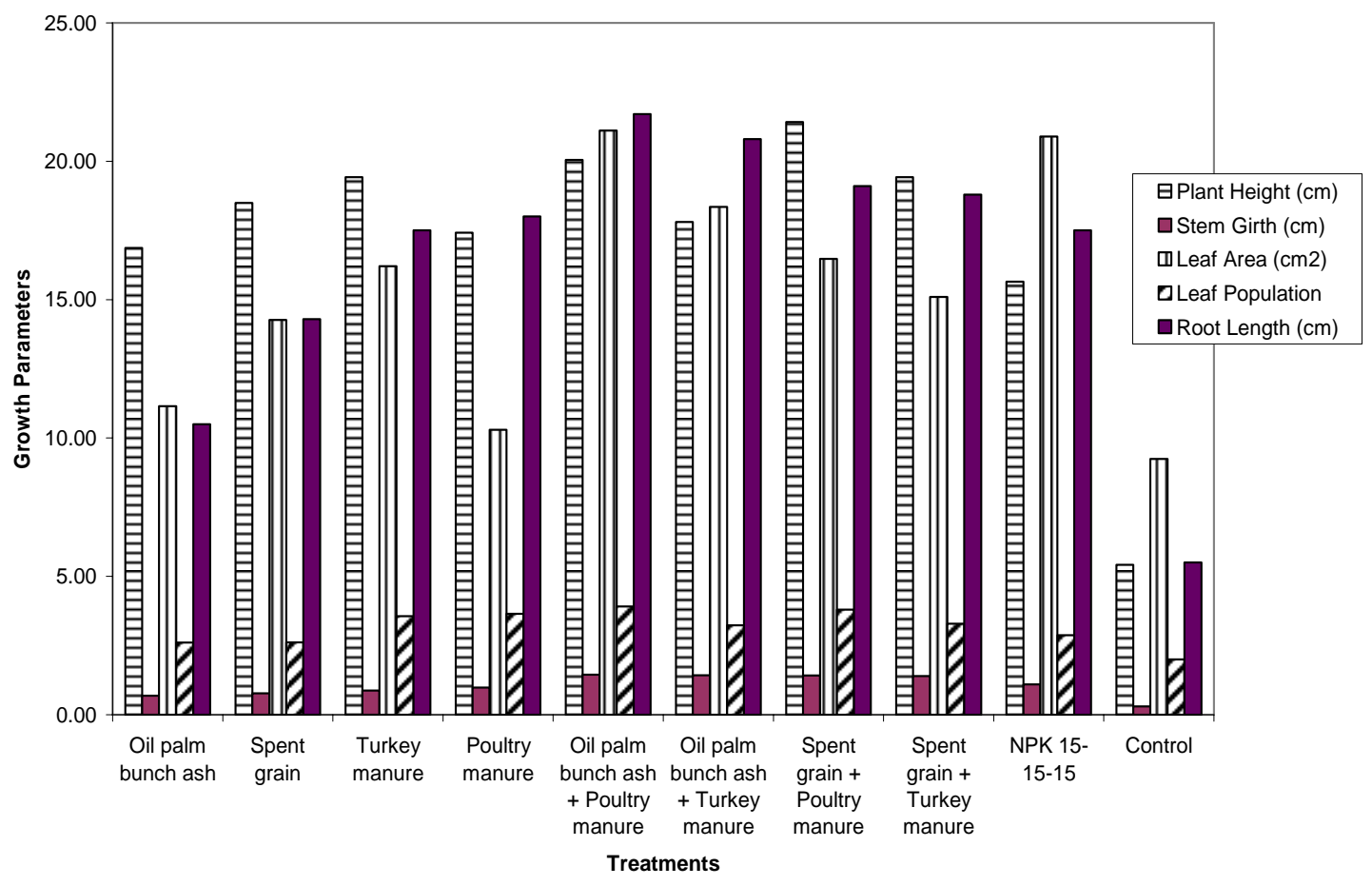

Fig. 3: Effect of different organic fertilizer on the growth performance of mango seedlings

Table 1. Correlation coefficients ( $r$ ) between the growth parameters of mango seedlings under different organic fertilizers.

\begin{tabular}{lc}
\hline Growth parameters & "r" values \\
\hline Plant height vs. Stem girth & $0.759^{*}$ \\
Plant height vs. Leaf area & $0.516^{*}$ \\
Plant height vs. Leaf population & $0.799^{* *}$ \\
Plant height vs. root length & $0.816^{* *}$ \\
Stem girth vs. Leaf area & $0.727^{*}$ \\
Stem girth vs. Leaf population & $0.790^{* *}$ \\
Stem girth vs. root length & $0.931^{* *}$ \\
Leaf area vs. Leaf population & $0.495 \mathrm{n.s}$ \\
Leaf area vs. root length & $0.741^{*}$ \\
\hline
\end{tabular}

**is significant at $1 \%, *$ is significant at $5 \%$ level, ns is not significant 


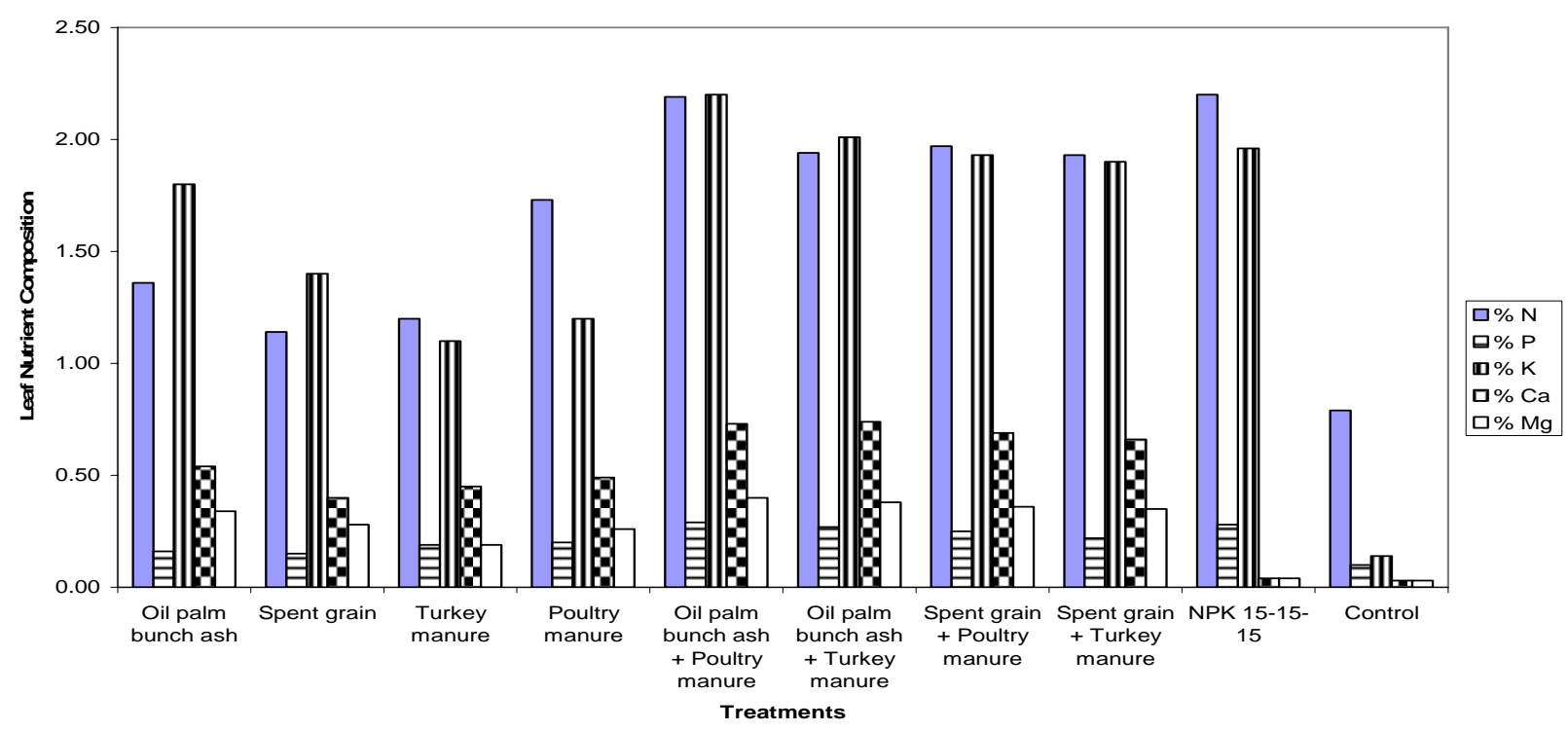

Fig. 4: Effect of different organic fertilizers on the leaf nutrient composition of mango seedlings

Table 2. Correlation coefficients ( $r$ ) between the leaf mineral composition and growth parameters of mango seedlings under different organic fertilizers.

\begin{tabular}{lccccc}
\hline & \multicolumn{5}{c}{ Leaf mineral composition } \\
\cline { 2 - 6 } Growth Parameters & $\mathbf{N}$ & $\mathbf{P}$ & $\mathbf{K}$ & $\mathbf{C a}$ & $\mathbf{M g}$ \\
\cline { 2 - 6 } Plant height & $0.582^{*}$ & $0.610^{*}$ & $0.768^{* *}$ & $0.758^{* *}$ & $0.731^{*}$ \\
Stem girth & $0.892^{* *}$ & $0.90^{* *}$ & $0.841^{* *}$ & $0.72^{*}$ & $0.648^{*}$ \\
Leaf area & $0.738^{*}$ & $0.873^{* *}$ & $0.723^{*}$ & $0.25 \mathrm{~ns}$ & $0.195 \mathrm{~ns}$ \\
Leaf population & $0.663^{*}$ & $0.707^{*}$ & $0.557^{*}$ & $0.702^{*}$ & $0.0580^{*}$ \\
Root length & $0.824^{* *}$ & $0.883^{* *}$ & $0.753^{*}$ & $0.656^{*}$ & $0.561^{*}$ \\
\hline
\end{tabular}

(a) ** Significant at $1 \% *$ Significant at $5 \%$ ns Not Significant

\section{Effect of Organic Fertilizers on Soil Chemical Composition after the Experiment}

The organic fertilizers increased the soil $\mathrm{N}, \mathrm{P}, \mathrm{K}, \mathrm{Ca}, \mathrm{Mg}, \mathrm{pH}$ and O.M significantly $(\mathrm{P}<0.05)$ relative to the control treatment (Figures 5).

Oil palm bunch ash + poultry manure treatment increased the soil $\mathrm{pH}\left(\mathrm{H}_{2} \mathrm{O}\right)$, O.M, N, P, Ca and $\mathrm{Mg}$ by $18 \%, 79 \%$, $23 \%, 26 \%, 99.2 \%$ and $99.1 \%$ compared to NPK 15-15-15 fertilizer. However, the NPK 15-15-15 fertilizer increased soil K by $10 \%$ compared to the oil palm bunch ash + poultry manure.

Generally, the amended forms of oil palm bunch ash and spent grain with poultry and turkey manures increased significantly $(\mathrm{P}<0.05)$ the values of soil $\mathrm{N}, \mathrm{P}, \mathrm{K}, \mathrm{Ca}, \mathrm{Mg}, \mathrm{pH}$ and O.M more than their sole applications (turkey, poultry manures, spent grain and oil palm bunch ash). For instance, the oil palm bunch ash + poultry manure increased soil $\mathrm{pH}$ $\left(\mathrm{H}_{2} \mathrm{O}\right)$ O.M, N, P, K, Ca and $\mathrm{Mg}$ by $5 \%$, $29 \%, 27 \%, 37 \%, 35 \% 46 \%$ and $38 \%$ 
respectively compared to the poultry manure treatment.

Among the amended forms of oil palm bunch ash and spent grain with poultry and turkey manure, the oil palm bunch ash + poultry manure treatment had the highest values of soil $\mathrm{pH}\left(\mathrm{H}_{2} \mathrm{O}\right), \mathrm{O} . \mathrm{M}, \mathrm{N}$, $\mathrm{P}, \mathrm{K}, \mathrm{Ca}$ and $\mathrm{Mg}$ compared to other treatments. For instance, oil palm bunch ash + poultry manure treatment increased the soil $\mathrm{pH}\left(\mathrm{H}_{2} \mathrm{O}\right), \mathrm{O} . \mathrm{M}, \mathrm{N}, \mathrm{P}, \mathrm{K}, \mathrm{Ca}$ and $\mathrm{Mg}$ by $2 \%, 12 \%, 13 \%, 35 \%, 5 \%, 12.8 \%$ and $28 \%$ respectively compared to spent grain + turkey manure treatment.

Oil palm bunch ash + turkey manure had better values of soil $\mathrm{N}, \mathrm{P}, \mathrm{K}, \mathrm{Ca}$, and $\mathrm{Mg}$ than spent grain + poultry manure treatment except soil $\mathrm{pH}\left(\mathrm{H}_{2} \mathrm{O}\right), \mathrm{O}$. M. and $\mathrm{Ca}$.

The spent grain + poultry manures treatment had better values of soil $\mathrm{pH}$ $\left(\mathrm{H}_{2} \mathrm{O}\right)$, O.M, N, P, and Ca while oil palm bunch ash had the highest values of soil $\mathrm{pH}\left(\mathrm{H}_{2} \mathrm{O}\right), \mathrm{K}$ and $\mathrm{Mg}$ respectively.
The soil $\mathrm{K} / \mathrm{Ca}, \mathrm{K} / \mathrm{Mg}$ and $\mathrm{P} / \mathrm{Mg}$ ratios in NPK 15-15-15 fertilizer treatment were 131:1, 197:1 and 1335: 0 compared to $\mathrm{K} / \mathrm{Ca}(1: 1), \mathrm{K} / \mathrm{Mg}(2: 1)$ and $\mathrm{P} / \mathrm{Mg}(17: 1)$ in oil palm bunch ash + poultry manure treatment.

The correlation ( $\mathrm{r}$ ) values between soil $\mathrm{pH} \mathrm{N}, \mathrm{P}, \mathrm{K}, \mathrm{Ca}, \mathrm{Mg}, \mathrm{pH}, \mathrm{O} . \mathrm{M}$ and growth parameters (plant height, leaf area, stem girth, leaf population and root length) of mango seedlings were positive and significant at $(\mathrm{P}<0.01$ and 0.05$)$ Table 3 signifying the importance of the positive relationship between soil nutrients and growth parameters of mango seedlings. For instance, the " $r$ " values between plant height and soil N, plant height and soil $\mathrm{O}$. $\mathrm{M}$, stem girth and soil $\mathrm{P}$, leaf area and soil $\mathrm{K}$, root length and soil $\mathrm{N}$, root length and soil $\mathrm{Ca}$ were $0.686,0.718,0.869$, $0.699,0.916$ and 0.710 respectively at $1 \%$ and $5 \%$ level of significance.

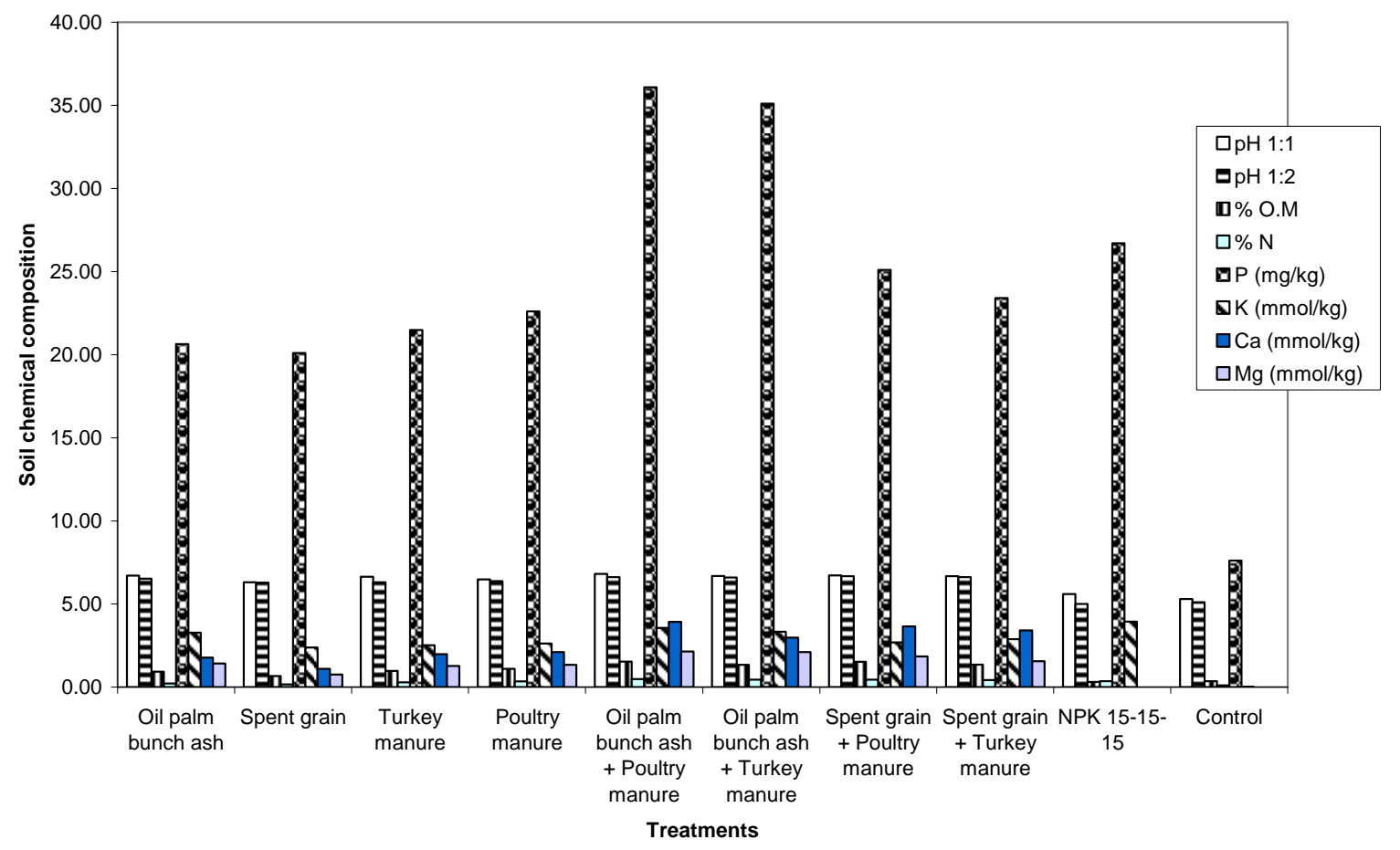

Fig. 5: Effect of different organic fertilizer on the soil chemical composition 
Table 3. Correlation coefficients (r) between the soil nutrient composition and growth parameters of mango seedlings under different organic fertilizers.

\begin{tabular}{lcccccccc}
\hline & Soil pH & Soil pH & $\mathbf{O . M}$ & $\mathbf{N}$ & $\mathbf{P}$ & $\mathbf{K}$ & $\mathbf{C a}$ & $\mathbf{M g}$ \\
\hline Plant height & $0.853^{* *}$ & $0.773^{* *}$ & $0.718^{* *}$ & $0.686^{*}$ & $0.692^{*}$ & $0.741^{* *}$ & $0.72^{*}$ & $0.714^{*}$ \\
Stem girth & $0.625^{*}$ & $0.561^{*}$ & $0.779^{*}$ & $0.970^{* *}$ & $0.869^{* *}$ & $0.699^{*}$ & $0.797^{*}$ & $0.718^{*}$ \\
Leaf area & $0.226 \mathrm{~ns}$ & $0.077 \mathrm{~ns}$ & $0.291 \mathrm{~ns}$ & $0.703^{*}$ & $0.803^{*}$ & $0.699^{*}$ & $0.340 \mathrm{~ns}$ & $0.29 \mathrm{~ns}$ \\
Leaf population & $0.726^{*}$ & $0.640^{*}$ & $0.809^{*}$ & $0.828^{* *}$ & $0.695^{*}$ & $0.539^{*}$ & $0.801^{* *}$ & $0.742^{*}$ \\
Root length & $0.637^{*}$ & $0.541^{*}$ & $0.703^{*}$ & $0.916^{* *}$ & $0.885^{* *}$ & $0.734^{*}$ & $0.710^{*}$ & $0.672^{*}$ \\
\hline ** is significant at $1 \% *$ is & & &
\end{tabular}

** is significant at $1 \%, *$ is significant at $5 \%$, ns is Not Significant

\section{Discussion}

The least values of growth parameters of mango seedlings, leaf and soil N, P, K, $\mathrm{Ca}, \mathrm{Mg}, \mathrm{pH}$ and $\mathrm{O} . \mathrm{M}$ in the control treatment could be traced to the initial poor nutrient status of the soil and continuous cultivation without fertilization. This observation could be responsible for the deficiency symptoms of yellow and purple colorations and marginal burn of leaves consistent with $\mathrm{N}, \mathrm{P}, \mathrm{K}$, or $\mathrm{Mg}$ deficiencies.

This finding agreed with the work of Adepetu et al. (1978) which reported an approximate $58 \%$ drop in soil O.M over seven years of continuously cultivating an Iwo Soil Association in the greenhouse and under field conditions without fertilization.

The effectiveness of spent grain and oil palm bunch ash in improving the growth, soil and leaf mineral composition of mango seedlings, when mixed with poultry and turkey manures can be attributed to enhancement of their degradation rate by the manures with lower $\mathrm{C} / \mathrm{N}$ ratio. However, the initial processing of the organic fertilizers before application to the soil should have further enhanced their decomposition and rate of nutrient release to the soil.

This observation might be responsible for the marked difference in the performance of the spent grain, oil palm bunch ash amended with poultry and turkey manure compared to the previous work of Adebayo and Olayinka (1984) which used the unprocessed forms of oil palm bunch ash and sawdust amended with poultry and turkey manures for maize production.

The observed performance of oil palm bunch ash + poultry manure treatment in increasing the growth parameters of mango seedlings compared to the NPK 15-15-15 fertilizer could be due to their rich nutrient contents which increased the soil nutrients and subsequently improved nutrient and water uptake in the plants. The same trend of performance was obtained for the leaf mineral composition and soil nutrients as noticed in the significant " $r$ " values between the plant height and soil $\mathrm{N}$, root length and soil $\mathrm{Ca}$, plant height and leaf $\mathrm{K}$, stem girth and leaf $P$ respectively.

The higher values of root length under the spent grain + poultry manure and oil palm bunch ash + poultry manure compared to NPK fertilizer could be due to the fact that these organic materials reduced soil bulk density, thus enhancing the soil structural condition and root growth. This observation agreed with Folorunso (1999) and Moyin-Jesu (2003) and Moyin-Jesu (2006) who reported that spent grain, oil palm bunch ash and their amendments reduced soil bulk density and enhanced better root growth. 
The low values of soil O.M., $\mathrm{pH}, \mathrm{Ca}$ and $\mathrm{Mg}$ under NPK fertilizer treatment was due to the high soil $\mathrm{K} / \mathrm{Ca}$ and $\mathrm{K} / \mathrm{Mg}$ ratios which led to serious nutrient imbalances in the supply of $\mathrm{P}, \mathrm{K}, \mathrm{Ca}$ and $\mathrm{Mg}$ nutrients to crops. The observation is supported by Folorunso et al. (2000) who reported that high soil $\mathrm{K}$ resulted in nutrient imbalance with $\mathrm{Ca}$ and $\mathrm{Mg}$, thus, affecting their uptake by crops.

The excellent performances of the organic fertilizers amended with manures over their sole forms was due to the fact that turkey and poultry manures have high nutrient contents and low $\mathrm{C} / \mathrm{N}$ ratio and their combinations with spent grain and oil palm bunch ash fortified their nutrients supplying power. This finding explained the superiority in the growth parameters, leaf and soil chemical composition of mango seedlings in the amended oil palm bunch ash + poultry manure treatment compared to the sole forms, which was in line with the work of Moyin-Jesu (2004) who reported nutrient superiority of organically amended fertilizers over the sole forms in castor seed cultivation.

However, the performance of amended oil palm bunch ash + poultry manure treatment in increasing the growth, leaf and soil parameters of mango seedlings in this experiment was different from the work of Odedina (2007) who used cocoa husk amended with poultry manure to grow tomatoes. This difference might be due to the higher nutrient composition and lower $\mathrm{C} / \mathrm{N}$ ratio of oil palm ash than cocoa husk.

The increase in soil $\mathrm{pH}$ values in oil palm bunch ash and oil palm bunch ash + poultry manure compared to other treatments was traced to the high $\mathrm{K}$ and $\mathrm{Ca}$ contents of the two materials used for the experiment. Therefore, they could be effective as liming materials, unlike the NPK fertilizer which on continuous use decreased soil $\mathrm{pH}$ and O.M. Soil $\mathrm{pH}$ had been reported to influence nutrient uptake and availability to crops for optimum growth (Gordon, 1988).

The best performances oil palm ash + poultry manure among the amended treatments in improving growth, leaf and soil parameters could be traced the fact that poultry manure had the highest values of $\mathrm{N}, \mathrm{P}$ nutrients and least $\mathrm{C} / \mathrm{N}$ ratio while oil palm bunch ash had the highest amount of $\mathrm{K}, \mathrm{Ca}, \mathrm{Mg}, \mathrm{Fe}, \mathrm{Zn}$ and $\mathrm{Cu}$ nutrient.

This observation was similar to the work of Moyin-Jesu (2003b) who reported the performance of oil palm bunch ash + poultry manure in increasing the growth, leaf, and soil nutrients in oil palm seedlings.

The best performance of turkey manure in producing the highest value of plant height of mango seedlings could be traced to the fact its nutrient composition will help to increase water and nutrient supply to the seedlings for better growth.

\section{Conclusion and Recommendations}

The sole and amended forms of oil palm bunch ash and spent grain with poultry and turkey manures applied at 8 $\mathrm{t} / \mathrm{ha}$ (40 g/pot) increased the leaf mineral, soil chemical composition, and growth parameters of mango seedlings. It is recommended that oil palm bunch ash + poultry manure $(8 \mathrm{t} / \mathrm{ha})$ was the most effective fertilizer material for improving the nutrient availability and ensuring sustainable cultivation of mango seedlings on a commercial basis.

This recommendation agreed with the fact that inorganic fertilizers are becoming very expensive to purchase by small holding farmers of mango. These materials appear to also have beneficial secondary effects on soil properties and could be more favorable to the environment.

\section{References}

Adebayo, A. and A. Olayinka. 1984. The effect of methods of application of 
sawdust on plant growth, nutrient uptake, and soil chemical properties Ife Jour. of Agric. 2:36-44.

Adepetu, J. A., A. A. Adebayo, E. A. Aduayi and C.O. Alofe. 1978. A preliminary survey of the fertility status of soils in Ondo State under traditional cultivation. Ife Jour. of Agric. 1:134-149.

Aduayi, E. A. 1980. Effect of ammonium sulphate fertilization on soil chemical composition, fruit yield, and nutrient content of okra. Ife Jour. of Agric. 2(1):16-33.

Agbede, O. O. and B. A. Kalu. 1990. An assessment of fertilizer use under traditional cropping systems in the middle belt zone of Nigeria. In: Proceedings of the third national farming system research network workshop. Research Network Workshop. University of Calabar, Calabar, Nigeria. Pp. 15-16.

Agboola, A. A. and R. B. Corey. 1973. Soil testing N, P, K for maize in the soils derived from metamorphic and igneous rocks of Western State of Nigeria. Nigeria J. West African Sci. Assoc. 17:93-100.

AOAC. 1970. Official Methods of Analysis 12th ed. Association of Official Analytical Chemists. Arlington, VA.

Bouycous, H. 1951. Mechanical analysis soils using hydrometer method. Analytical Chem. Acta. 22:32-34.

Crockford, L. and R. Nowell. 1956. Laboratory manual of physical chemistry. Exp 31 and 32. John Wiley and Sons, New York.

Folorunso, O. O. 1999. Use of plant residues for improving soil fertility and yield of okra (Abelmoschus esculentum $L$ ) and Amaranthus viridis $L \quad$ Ph.D. dissertation, Federal University of Technology, Akure.

Folorunso, O. O., A. A. Agboola and G.O. Adeoye. 2000. Evaluation of three fertilizer models for $\mathrm{P}$ and $\mathrm{K}$ recommendation in maize (Zea Mays). Jour. of Technical Educ., 2:237-253.

Gordon, W. 1988. Coffee Tropical Agricultural series. In: H. Murray (Eds). Pp. 1-20. Macmillan Publishing Ltd. London.

Gomez, K. A. and A. A. Gomez. 1984. Statistical procedures for Agricultural Research $2^{\text {nd }}$ edition. John Wiley and Sons. New York.

Jackson, M. L. 1958. Soil Chemical Analysis. Englewood Cliffs N.J. Prentice Hall. 57-69.

Jackson, M. L. 1964. Soil Chemical Analysis. Englewood Cliffs, N. J. Prentice Hall. 86-92.

McLean, E. O. 1965. Aluminum P. 927932. MCA Black (eds). Methods of soil analysis part 2, Agronomy 9, Amer. Soc. Agron. Madison Wisconsin, U.S.A.

Moyin-Jesu, E. I. and B. Atoyosoye. 2002. Utilization of Agricultural Wastes for the growth, leaf and soil chemical composition of cocoa seedlings in the Nursery. Pertanika Jour. of Trop. Agric. Sci. Malaysia 26(1):49-58.

Moyin-Jesu, E. I. 2003. Incorporation of agro-industrial biomass and their effects on four successive crops of Amaranthus. Pertanika Jour. of Trop. Agric. Sci. 26(1):14-18. 
Moyin-Jesu, E. I. and E. F. Charles. 2003b. Raising oil palm seedlings in Urban Cities using sole and Amended Wood ash and Sawdust Manurial Treatments. Pertanika Jour. of Trop. Agric. Sci. Malaysia. 26:19-25.

Moyin-Jesu, E. I. 2004. Comparative evaluation of different plant residues on the soil and leaf chemical composition, growth and seed yield of castor Bean (Ricinus communis) Pertanika Jour. of Trop. Agric. Sci. 27(1):21-30.

Moyin-Jesu, E. I., and S. O. Ojeniyi. 2006: Effects of sole and amended plant residues on soil Nutrient contents and yield of Okra (Abelmoschus esculentum L). Discovery and Innovation Journal. 18(4): 318-326.

Moyin-Jesu, E. I. 2007. Effect of some organic fertilizers on soil and coffee (Coffee arabica L), Leaf chemical composition, and Growth. University of Khartoum Jour. of Agric. Sci. 15(1):52-70.

Murphy, J. and J. P. Riley. 1962. A modified single solution method for determination of phosphate in natural waters. Analytical Chem. Acta. 27:31-36.

Obatolu, C. R. 1995. Nutrient balance sheet of Alfisol grown to coffee and maize using organic fertilizers. In: Proceedings of the third annual conference of all African Soil Science Society "The international conference on soil management and environmental protection". University of Ibadan, Nigeria. Pp. 250-256.
Obi, M. E. and C. O. Ofonduru. 1997. The effects of soil amendments on soil physical properties of a severely degraded sandy loam soil in South Eastern Nigeria. In: Proceedings of twenty-fourth annual conference Soil Science Society of Nigeria "The national conference on soil management for food security". Usman Danfodio University, Sokoto, Nigeria. pp. 30-35.

Odedina, S. O. M. Awodun and S.O. Ojeniyi. 2007. Effect of cocoa husk on the soil fertility, leaf mineral composition and growth of tomatoes. Global Jour. Environ. Studies. 26(1): 6-12.

Ogunwale, J. A. and E. J. Udo. 1998. A laboratory manual for soil and plant analysis. Agronomy Dept. Univ. Of Ibadan, Nigeria. 201-206.

Sobulo, R. A. and O. A. Osiname. 1981. Soils and fertilizer use in Western Nigeria. Tech Bull. No.11. Institute of Agricultural Research and Training, University of Ife, Nigeria.

Soil Survey Staff. 1999. Soil Taxonomy. A basic system for soil classification for making and interpreting soil surveys. Agric.Handbook No. 436, USDA, Washington, D.C.

Walkley, A. and I .A. Black. 1934. An examination of degtajaroff method for determining soil organic acid filtration method. Soil Sci. 37:29-38.

Yadav, R. L. and S. R. Prassad. 1992. Conserving the organic matter content of soil to sustain sugarcane yield. Expl. Agric. 28:51-62. 